University of Windsor

Scholarship at UWindsor

2011

\title{
Antecedents and postcedents of satisfaction in business relationships in Canada
}

David Hutchinson Dr.

University of Windsor

Jang Singh

University of Windsor

Follow this and additional works at: https://scholar.uwindsor.ca/odettepub

Part of the Business Commons

\section{Recommended Citation}

Hutchinson, David Dr. and Singh, Jang. (2011). Antecedents and postcedents of satisfaction in business relationships in Canada. Internation Journal of Logistics Economics and Globalisation, 3 (4), 189-209. https://scholar.uwindsor.ca/odettepub/80

This Article is brought to you for free and open access by the Odette School of Business at Scholarship at UWindsor. It has been accepted for inclusion in Odette School of Business Publications by an authorized administrator of Scholarship at UWindsor. For more information, please contact scholarship@uwindsor.ca. 


\title{
Antecedents and postcedents of satisfaction in business relationships in Canada
}

\section{David Hutchinson* and Jang Singh}

Odette School of Business, University of Windsor, Windsor, ON, N9B 3P4, Canada

E-mail: dhutch@uwindsor.ca

E-mail: jang@uwindsor.ca

*Corresponding author

\section{Göran Svensson and Tore Mysen}

Oslo School of Management, P.O. Box 1195, Sentrum, 0107, Oslo, Norway

E-mail: goran.svensson@hh.se_E-mail: tore.mysen@mh.no

\begin{abstract}
This paper reports the findings of an investigation of whether trust and commitment influence satisfaction, and whether satisfaction then influences specific investments, opportunism, and formalisation. Using data collected in a survey of Canadian managers and executives, a model derived from marketing theory and previous empirical research was tested. The model includes both relationship marketing concepts and transaction cost theory concepts, an approach rarely encountered in existing studies. Satisfaction in an exchange relationship is formed by keeping promises in an iterative process, and serves as a safeguard against possible future risks (e.g., opportunism). Finally, we discuss the limitations of the study.
\end{abstract}

Keywords: relationship; quality; trust; commitment; satisfaction; specific investments; opportunism; formalisation.

Reference to this paper should be made as follows: Hutchinson, D., Singh, J., Svensson, G. and Mysen, T. (2011) 'Antecedents and postcedents of satisfaction in business relationships in Canada', Int. J. Logistics Economics and Globalisation, Vol. 3, No. 4, pp.189-209.

Biographical notes: David Hutchinson is an Assistant Professor of Marketing, with research interests in the area of business to business marketing and marketing education. He had worked in the sales and marketing area, for corporations such as $3 \mathrm{M}$ healthcare. He has since completed a $\mathrm{PhD}$ and is active in research involving simulation and gaming, and customer-supplier relationship marketing.

Jang Singh is Professor and Senior Research Leadership Chair at the Odette School of Business, University of Windsor, Canada. While he has published in many areas, his research focus is business ethics with particular emphasis on corporate codes of ethics. His research papers have been published in several scholarly journals including Journal of World Business, Journal of Business Ethics and Business and Society Review. 
Göran Svensson is a Professor at the Oslo School of Management, Norway. He is also Professor at Halmstad University, Sweden, Honorary Professor at Deakin University, Australia, and Visiting Professor at University of Johannesburg, South Africa. Furthermore, he is a committed member of the international research community as journal editor, sitting on numerous editorial boards and scholarly/research networks and associations. $\mathrm{He}$ is a frequent author of international journal articles and international conference contributions, is an invited speaker and is engaged as a book author. He has a background as an industrialist and entrepreneur in South America.

Tore Mysen is an Associate Professor at Oslo School of Management, Norway. He holds a Dr. Oecon (PhD) at Norwegian School of Management BI. He has background as an entrepreneur and from management and board positions within telecommunication industry. His research agenda consists of various subjects within inter-firm relationships, such as governance of foreign collaborative partners, coordination and cooperation, relationship management, relationship quality and relationship climate. He has published in various international journals. Furthermore, he is a member of editorial boards and is committed as track chair and session chair at conferences.

\section{Introduction}

In Terpend et al.'s (2008) review of research into buyer-supplier relationships they recommend that future studies consider using a complementary multi-theoretical perspective to explain exchange relationships. The current study investigated the connection between the relationship marketing (RM) concepts (trust, commitment, and satisfaction) and transaction cost theory concept (investments, opportunism, and formalisation). In other words, this study investigated traditional business to business (B2B) marketing relationship dimensions in relation to transactional outcomes, which can impact the future success of a business partnership. A review of the literature indicates that these concepts are rarely, if ever, investigated within the same study, yet they appear to be within a relationship continuum. However, there appears to be a contradiction in the literature regarding the direction of influence.

The dimensions trust, commitment and satisfaction appear to be included in a majority of the studies on business relationships (Geyskens et al., 1999; Naude and Buttle, 2000; Walter et al., 2000; Wetzels et al., 1998). A number of researchers have investigated these dimensions as part of a higher order construct, relationship quality, in B2B as well as business to consumer (B2C) situations (Dorsch et al., 1998; Hennig-Thurau and Klee, 1997; Hewett et al., 2002; Roberts et al., 2003; Shamdasani and Balakrishnan, 2000; Svensson et al., 2009; Walter et al., 2003; Wong and Sohal, 2002). In a number of studies, trust and commitment are presented as independent concepts (Hewett et al., 2002; Morgan and Hunt, 1994; Ruyter et al., 2001). In addition, others show satisfaction as a distinct concept from the trust and commitment dimensions (Geyskens et al., 1999; Ivens, 2004; Walter et al., 2003).

After a review of the literature on the relationship between these three dimensions it becomes apparent that there is no consensus. For example, studies on the higher order relationship quality concept suggest trust, satisfaction and commitment to be dimensions 
or antecedents of the construct (Hutchinson et al., 2010; Rauyruen and Miller, 2007; Roberts et al., 2003; Skarmeas et al., 2008; Skarmeas and Robson, 2008). In contrast, other researchers suggest that satisfaction is antecedent to trust and commitment (Ha and Muthaly, 2008; Hennig-Thurau et al., 2002; Moliner, 2007a, 2007b), while others suggest trust and commitment are antecedent to satisfaction (Farrelly and Quester, 2005; Walter et al., 2000), or only by trust as an antecedent (Anderson and Narus, 1990; Ganesan, 1994; Mohr and Spekman, 1994). Finally, it has been suggested that satisfaction is a mediator between trust and commitment and other outcomes (Garbarino and Johnson, 1999; Lee et al., 2010; Svensson et al., 2010).

The current study investigated the position that in an existing B2B situation satisfaction is an outcome of trust and commitment based on the following findings from the literature. According to Skarmeas et al. (2008), "satisfaction is a focal outcome of buyer-seller relationships that is generally unlikely to develop in the absence of trust and commitment" (p.25). Other studies also support the position that trust and/or commitment are antecedents to satisfaction (Anderson and Narus, 1990; Barclay and Smith, 1997; Farrelly and Quester, 2005; Ganesan, 1994; Grewal et al., 1999; Johnson et al., 2008; Mohr and Spekman, 1994; Payan and Svensson, 2007; Roath and Sinkovics, 2006; Wong and Zhou, 2006). Also, according to the literature, satisfaction appears to have a stronger influence on certain outcomes than trust (Leonidou et al., 2006; Rauyruen and Miller, 2007; Ulaga and Eggert, 2006), as well as a stronger influence with certain outcomes than commitment (Bansal et al., 2004; Lang and Colgate, 2003; Rauyruen and Miller, 2007). According to Moliner et al. (2007a), “...the fundamental variable in a customer's perception of relationship quality is the customer's satisfaction" (p.1415). Therefore, the literature suggests that satisfaction may have a greater influence on outcomes that trust and commitment.

As suggested earlier the dimensions of RM intuitively appears to be part of a continuum with the dimensions of transactional cost analysis (TCA). Geyskens et al. (1998) suggest that trust influences satisfaction and has an effect on economic outcomes. In addition, they suggest that trust, a dimension of RM, has an influence on the dimensions of TCA; opportunistic behaviour and a willingness to invest. In contrast, Handfield and Bechtel (2002) suggest that site specific assets, considered a dimension of TCA, influences trust in B2B situations. We argue that RM dimensions influence the dimensions of TCA as indicated by Geyskens et al. (1998). However, our review of the literature suggests that satisfaction dimension acts as a mediating dimension.

In summary, this paper proposes to investigate whether trust and commitment influence satisfaction, and whether satisfaction then influences specific investments, opportunism, and formalisation. The following sections of this paper present a conceptual model and hypotheses, and then outline the methodology, data analysis, and results. Finally, the conclusions and limitations are presented.

\section{Conceptual model and hypotheses}

The proposed model presented in Figure 1 positions trust and commitment as antecedent to satisfaction. Satisfaction is also positioned as antecedent to the outcomes of specific investments, opportunism, and formalisation. 
Figure 1 An inter-organisational RM and transaction cost model (see online version for colours)

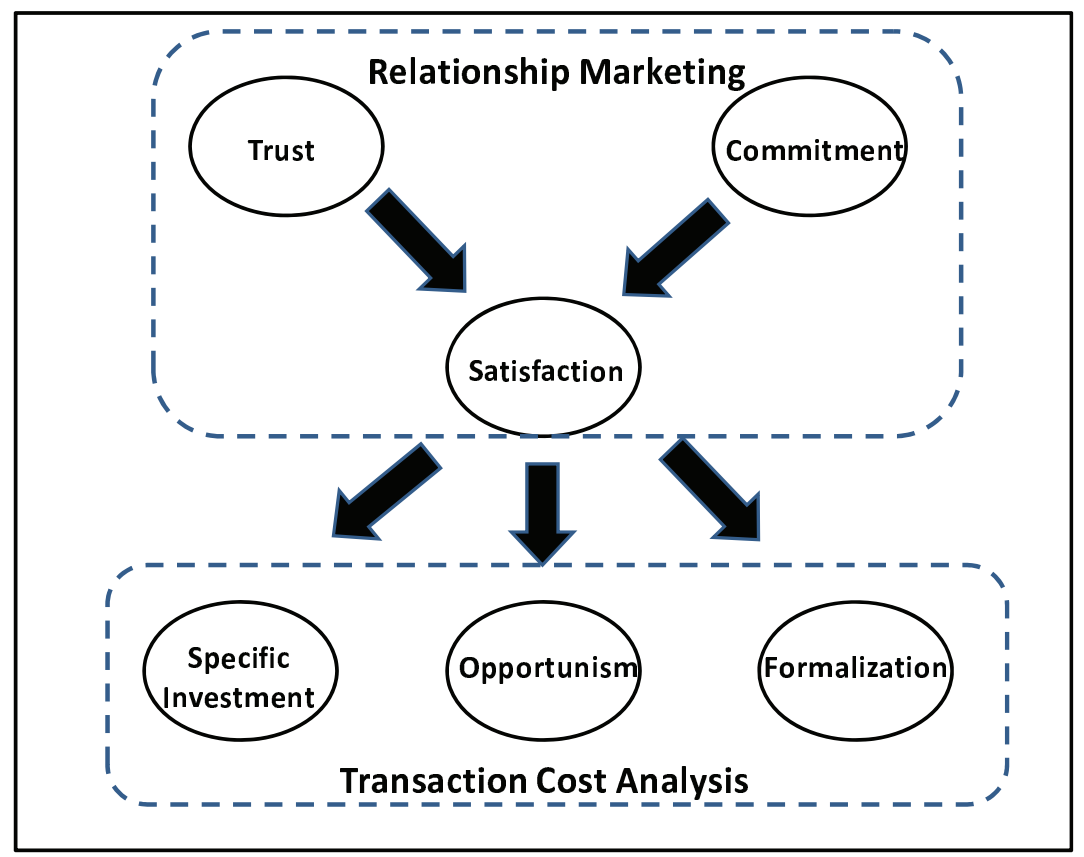

\section{TCA and RM theories}

Williamson's (1975) influential work on transaction costs heighten a significant stream of research in the marketing area where TCA focused on the transaction and the economic exchange between customers and sellers; due in part to the reliance of early marketing works on economic paradigms (Sharma and Pillai, 2003). A key concept or factor within TCA research is specific investments or assets of high importance within focal exchange relationship (Anderson, 1985; Heide and John, 1990; Rindfleisch and Heide, 1997; Weiss and Anderson, 1992). These specific investments or assets, according to TCA, can create a problem for organisations that invest. Since specific investments may be of less value in future situations, there is an incentive for an opportunistic organisation to expropriate the returns through ex post bargaining or threat of termination (Klein et al., 1978; Lui et al., 2009). In addition, organisations may safeguard the investments or assets ex ante by formalisation of the partnership with contracts between the exchange partners (Buvik and Reve, 2001; Klein et al., 1978; Lui et al., 2009). In summary, because of their importance to TCA, this study includes the concepts: specific investments, opportunism, and formalisation. These concepts suggest that partnerships may operate on an arm's length continuum depending on the extent of the formalisation.

Alternatively, RM theory and research focus on a willingness to accommodate the needs of exchange partners in developing relationships in the long-term (Lui et al., 2009). One of the most widely cited studies in the literature on B2B RM is by Morgan and Hunt (1994), which suggested that trust and commitment were major factors in developing 
exchange relationships. There is also a significant number of studies that indicate the importance of satisfaction as a key factor in developing exchange relationships (Barclay and Smith, 1997; Farrelly and Quester, 2005; Johnson et al., 2008; Mohr and Spekman, 1994; Payan and Svensson, 2007; Roath and Sinkovics, 2006; Skarmeas et al., 2008; Wong and Zhou, 2006). According to the literature, the concepts trust, commitment, and satisfaction appear to be the most frequently studied RM concepts (Barry et al., 2008; Caceres and Paparoidamis, 2007; Naude and Buttle, 2000; Palmatier et al., 2006) and are therefore included in this study.

According to Sharma and Pillai (2003) "the emergence of customer relationship management (CRM) systems, coupled with access to better customer cost" (p.623) considerations, from a TCA perspective, have assisted marketers to investigate alternative marketing strategies. Therefore, this study includes key concepts from both TCA and RM theories. However, TCA factors (specific investments, opportunism, formalisation) appear to be at the opposite end of a continuum from RM concepts (trust, commitment, satisfaction), which may explain the limited theoretical discussion in the literature concerning a direct connection. However, authors such as Young and Wilkinson (1989) indicate that transaction costs are lower when exchange partners work in an atmosphere of trust. In addition, Parkhe (1993) indicates that the length of time one organisation expects to do business with another organisation (i.e., perceived commitment) suggests lower vulnerability in the exchange relationship and therefore potentially lower transaction costs.

This study does not propose investigating a direct link between the marketing relationship concepts trust and commitment, and the TCA concepts specific investments, opportunism, and formalisation. Rather this study positions the marketing construct satisfaction as a mediator between the RM concepts (trust and commitment) and TCA outcomes. As indicated, satisfaction in an exchange relationship has been positioned as an outcome of trust and commitment. In addition, satisfaction appears to have a stronger influence on certain outcomes relative to trust and commitment. In summary, this study plans to investigate whether satisfaction serves as a more proximal cause of outcomes than trust or commitment. Specific hypotheses are presented in subsequent sections.

\section{Trust and commitment antecedent to satisfaction}

Satisfaction has been defined as a positive affective state resulting from the appraisal of the working relationship between organisations (Geyskens et al., 1999). Satisfaction has also been defined as an effective state resulting from the evaluation about the exchange performance compared to expectations (Oliver, 1997; Wilson, 1995). Evaluations can encompass all aspects of an exchange relationship (Geyskens et al., 1999), which include tangible and intangible aspects of the relationship (Parsons, 2002). The evaluation of a supplier's performance versus expectations includes the marketing relationship variables trust and commitment. Duarte and Davis (2004) note that in B2B research customer satisfaction is considered an outcome construct, which is supported by empirical research (Duarte and Davies, 2004; Huntley, 2006; Skinner et al., 1992). Therefore, in this study satisfaction is the focal outcome in a buyer-seller exchange relationship, which is unlikely to develop into a long term relationship without trust and commitment (Skarmeas et al., 2008). 
Unlike satisfaction, there appears to be little consensus on the definition of trust in an exchange relationship, possibly because of the multifaceted use of the word. Moorman et al. (1992) define trust as a willingness of an organisation to rely on an exchange partner in whom one has confidence. Trust is also viewed as a belief, confidence, or expectation, about an exchange partner's trustworthiness based on the partner's expertise, reliability and intentionality (Moorman et al., 1993). Moorman et al. (1993) also suggest that trust is viewed as a behavioural intention regarding reliance on a partner or vulnerability. In addition, Mayer et al. (1995) state, "the definition of trust proposed in this research is the willingness of a party to be vulnerable to the actions of another party based on the expectation that the other will perform a particular action important to the trustor, irrespective of the ability to monitor or control that other party" (p.712). In summary, trustworthiness appears to be antecedent of trust and consists of integrity, benevolence, and competence of trustees.

Morgan and Hunt (1994) define trust based on confidence in an exchange partner's reliability and "integrity, which are associated with such qualities as consistent, competent, honest, fair, responsible, helpful, and benevolent" (p.23). However, they assume trust implied behavioural intentions and therefore did not distinguish trust from trustworthiness. Recently it has been suggested that that trust is more complex and should include aspects of capability, benevolence, and integrity (Bakker et al., 2006), honesty and confidence or credibility (Coote et al., 2003; Coulter and Coulter, 2003).

Addressing the role of benevolence in trust, Schoorman et al. (2007) state,

"While we may be able to identify situations, such as sole proprietorships, where the owners have strong bonds that display significant benevolence toward one another, the more traditional mode is probably one wherein each company is motivated primarily by its own financial interests. If this is indeed the norm, benevolence is not likely to be the most important factor in the development of inter-organizational trust." (p.345)

Therefore, this study downplays the role of benevolence in trust because of the interorganisational context.

This study adapts the definition of inter-organisational trust as the expectations that another organisation can be relied on to fulfil obligations, and will act and negotiate fairly (Zaheer et al., 1998). Zaheer's et al. (1998) definition is used because it downplays benevolence and is applicable to different levels of analysis appropriate to an interorganisational context (i.e., both inter-organisational and interpersonal boundary spanners) rather than being focused on intention based concerns of personal relationships.

In summary, if an exchange partner anticipates that they can rely on another organisation to act and negotiate fairly, the partner will be more satisfied with the relationship. As discussed earlier, satisfaction results from an overall evaluation of an exchange relationship, which includes assessing the fairness and honesty in the exchange. A high level of trust in an exchange partner will result in a positive affective outcome such as satisfaction in the relationship. Positioning trust as antecedent to satisfaction is supported by a number of studies (Andaleeb, 1996; Duarte and Davies, 2004; Lee et al., 2010; Mohr and Spekman, 1994; Schul et al., 1985; Svensson et al., 2010).

H1 Trust has a positive influence on satisfaction.

This study defines commitment as an enduring (affective) desire to maintain a valued relationship (Moorman et al., 1992). In support, Morgan and Hunt (1994) define commitment "as an exchange partner believing that an ongoing relationship with another 
is so important as to warrant maximum efforts at maintaining it; that is, the committed party believes the relationship is worth working on to ensure that it endures indefinitely" (p.23). Commitment, one of the most studied concepts in organisational behaviour theory, has long been central to RM and can distinguish between social and economic exchange (Morgan and Hunt, 1994). That these definitions of commitment have stood the test of time is illustrated by Coote et al.'s (2003) recent definition of the concept as a long-term exchange between partners enduring desire to maintain a valued relationship.

Commitment to an exchange relationship results from a desire to develop a stable long-term relationship and a willingness to make short-term sacrifices to maintain the relationship (Anderson and Weitz, 1992). A customer's satisfaction will be, in part, determined by the customer's investment in maintaining the business relationship. For example, the buyer may stress the accuracy in specifying requirements and in involving the seller in key decisions. Clear specifications and more active involvement in the process make it easier for the seller to meet the buyer's expectations, which is a factor in a positive evaluation (satisfaction) of the exchange relationship. In support, Mohr and Spekman (1994) and Farrelly and Questar (2005) indicate that commitment leads to satisfaction with business relationships.

H2 Commitment has a positive influence on satisfaction.

\section{Specific investments, opportunism and formalisation as outcomes of satisfaction}

A customer's perception of fulfilment (Oliver, 1997) or satisfaction is influenced by the evaluation of all dimensions of the exchange relationship between the buyer and the seller (Anderson and Narus, 1990). As discussed earlier, the satisfaction construct is generally considered an affective state of mind (Anderson and Narus, 1990), and may be influenced by the buyer's evaluation of previous relational exchange factors including established trust and commitment.

\subsection{Satisfaction and specific investments}

The term specific investments (specific assets) are defined as dedicated activities and resources employed jointly between exchange organisations (Anderson et al., 1994) and represent investments that have little value outside a particular exchange relationship (Rindfleisch and Heide, 1997). A specific (dedicated) investment is then at risk because it is not available for an alternative opportunity. If the investing organisation is satisfied with the exchange relationship then they will have confidence in future investments and therefore, the perception of risk will be reduced for the specific investment. In summary, satisfaction will influence specific investments positively.

\subsection{Satisfaction and opportunism}

Opportunism is defined as 'self-seeking behaviour with guile' [Williamson, (1975), p.26]. Guile involves 'deceitfulness', 'a lack of candour or honesty in transactions' (ibid., p.9). Opportunistic behaviour may include 'hidden information' or 'hidden action' 
[Bergen et al., (1992), p.3]. These types of opportunistic behaviour pose a risk to a long term exchange relationship.

The exchange relationship may carry on if the exchange partners perceive satisfaction from the relationship. If organisations are satisfied with the exchange relationship they will have confidence and renewed expectations that future dealings will be positive (positive reinforcement), which may minimise opportunistic behaviour. According to Ping (2007), as satisfaction with a relationship declines and becomes less rewarding, organisations are more likely to emit 'negative' behaviours such as opportunism or 'surreptitious self-interest seeking' (p.41) In summary, satisfaction is negatively associated with opportunism (Anderson, 1988; Pfeffer and Salancik, 1978; Ping, 1993).

\subsection{Formalisation and satisfaction}

According to Scott (1987), formalisation refers to: “...the degree to which rules prescribing behaviour are formulated, as well as the extent to which role responsibilities are prescribed" (p.33). According to Hawkins et al. (2009),

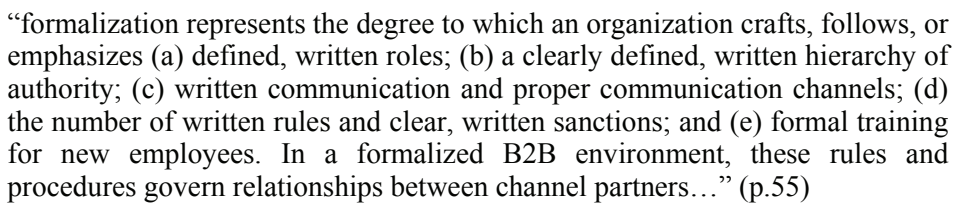
emphasizes (a) defined, written roles; (b) a clearly defined, written hierarchy of authority; (c) written communication and proper communication channels; (d) the number of written rules and clear, written sanctions; and (e) formal training for new employees. In a formalized B2B environment, these rules and procedures govern relationships between channel partners..." (p.55)

The formalisations may include the extent to which the relationship between exchange partners is regulated by contracts, rules and procedures. Formal arrangements will guide the behaviour of the participants in the supply chain and reflect a coordinating strategy between buyers and sellers (Xu and Beamon, 2006). According to Palmatier et al. (2006), formalisation is positioned as an outcome of relationship satisfaction. A firm that is satisfied with another firm will be more cooperating and willing to engage in the level of communication and adaptation, which are required to formulate contracts and exchange procedures (i.e., formalisation). In partial support Atkin and Rinehart (2006) show that satisfaction is positively associated with formalisation (e.g., formalised contracts).

H3 Satisfaction relates positively to specific investments.

H4 Satisfaction relates negatively to opportunism.

H5 Satisfaction relates positively to formalisation.

\section{Method}

\subsection{Research context and sample}

The relationships proposed in Figure 1 were tested. These relationships were derived from marketing theory and previous empirical research. The overall model positions trust and commitment as antecedent to satisfaction and satisfaction in turn is positioned as antecedent to the outcomes of specific investments, opportunism, and formalisation.

The sample consisted of managers and executives in small to large sized organisations (revenue of $\$ 2$ million to 153 billion) in Canada. The data were collected in 
2009 in three waves, with a determined effort to maximise participation and ensure a representative list of respondents. In the first wave, recipients of the newsletter of a national association of purchasing professionals were invited to complete an online survey. The association estimates that the newsletter is received by 7,000 persons. However, organisations may have two to three recipients of the association newsletter. A second request was sent to approximately 2,700 members of a group whose members are highly likely to also be members of the national association. In the third wave of data collection, the research instrument was sent to 774 named officers of Canada's largest corporations (with 101 of these returned as the named official had left the company). This group is also likely a subset of the national association. The data were therefore collected in a cascading manner to maximise the rate of return. This data collection process yielded 165 downloaded returns, seven letters stating that the request was forwarded to the purchasing department, eight letters indicating that it was company policy not to respond to surveys and five indicating that the addressee had left the company. Fifteen of the completed questionnaires were discarded for being incomplete or as outliers. The useable 150 questionnaires were from respondents representing a broad cross section of Canadian purchasing professionals.

Slightly more than $38.7 \%$ of the 150 respondents were from privately owned firms and $45.3 \%$ were from publicly owned firms. The other respondents were employed in firms owned by suppliers, manufacturers, cooperatives, etc. The number of years the organisations have worked with their current supplier ranged from one to 90, with a mean of 13.6 years. Of the 150 respondents, 94 are males and 56 females. One hundred and eighteen $(78.7 \%)$ of the respondents are university educated, ten $(6.7 \%)$ reported high school as their highest level of education attained, $2(1.3 \%)$ reported grade school and 20 $(13.3 \%)$ identified 'other' as their highest level of education. The length of employment of the respondents with their current employers ranged from six months to 37 years (mean length of service was 9.4 years) and their experience in the industry ranged from six months to 38 years ( mean experience was 14 years).

As suggested by Campbell (1955), the survey instrument includes two items as informant competency checks. The two items ask how much the respondent knew about his/her firm's perspective of the study topics and how much the respondent knew about specific experiences with its suppliers. A total of $98.8 \%$ of the respondents indicated that they had a good amount of knowledge about their firm's perspective in regard its suppliers and $99.4 \%$ indicated that they also had a good amount of knowledge about their firm's experiences with their suppliers. Consequently, all 150 questionnaires were used in the data analysis.

\subsubsection{Measures and scale items}

The measures used this study that support the inter-organisational RM and transaction cost model (see Figure 1) are based upon the following sources:

- causes

a trust - items were adapted from Zaheer et al. (1998)

b commitment - items were adapted from Morgan and Hunt (1994) and Anderson and Weitz (1992) 
- mediator

- $\quad$ satisfaction - items were adapted from Andaleeb (1996)

- outcomes

- $\quad$ specific investments - items were adapted from Heide and John (1990)

- opportunism - items were adapted from Dahlstrom and Nygaard (1999), John (1984) and Provan and Skinner (1989)

- formalisation - items were adapted from Dahlstrom and Nygaard (1999).

Informants responded to five-point Likert-type scales for all variables. These measures were anchored at (5) strongly agree and (1) strongly disagree (see Table 1).

Table 1 Scale items

Trust

a This supplier has always been fair in its negotiations with us.

b We can rely on this supplier to keep promises made to us.

c This supplier is trustworthy.

$$
\text { Commitment }
$$

a We intend to do business with this supplier well into the future.

b We are dedicated to continuing doing business with this supplier.

c We are resolute about future intent to do business with this supplier.

\begin{tabular}{ll}
\hline & \multicolumn{1}{c}{ Satisfaction } \\
\hline $\mathrm{a}$ & The relationship between us and this supplier is positive. \\
$\mathrm{b}$ & Our relationship with this supplier reflects a happy situation. \\
$\mathrm{c}$ & The relationship between the two firms is satisfying. \\
\hline & \multicolumn{1}{c}{ Specific investments } \\
\hline $\mathrm{a}$ & We have customised an essential share of our business in dealing with this supplier. \\
$\mathrm{b}$ & We have tailored parts of our business to accommodate the needs of this supplier. \\
$\mathrm{c}$ & We have aligned parts of our activities with those of this supplier. \\
\hline & $\quad$ Opportunism \\
\hline a & This supplier has not kept what he promised when we entered into the relationship. \\
b & Sometimes, this supplier has altered the facts slightly in order to get what they need. \\
c & This supplier is not always honest with us. \\
\hline & \\
\hline a & There is a clear distribution of tasks between us and this supplier. \\
b & In general, the information routines from this supplier are very clear. \\
c & There are well-established information routines between us and this supplier. \\
\hline
\end{tabular}

\subsubsection{Goodness of fit measures - measurement model}

To examine and test the measurement properties among the constructs of the conceptual model, confirmatory factor analysis was used (Jöreskog and Sorbom, 1976). Confirmatory factor analysis was run with a six construct measurement model (i.e., 
18 indicator variables as shown in Figure 2) using the SPSS/AMOS 16.0 software. When the measurement model was tested the goodness-of-fit measures were all well within recommended guidelines [Hair et al., (2006), pp.745-749]. For example, the chi-square $\left(X^{2}\right)$ was 194.859 with 120 degrees of freedom. This chi-square was statistically significant $(p=0.000)$ and may be due to the sample size $(N=150)$. As a result, other fit statistics were examined. The normed chi-square $\left(X^{2} / d f\right)$ was 1.624 while the NFI was 0.91 , the IFI was 0.96 , the TLI was 0.95 , the CFI was 0.96 , and RMSEA was 0.065 (confidence interval 90\%: 0.048-0.081). All of these fit statistics are within recommended guidelines. Based upon the satisfactory findings in testing the measurement model, all of the items for all six scales were retained for testing this study's hypotheses. Both the structural model and hypotheses tested are shown in Figure 2.

Figure 2 Six construct structural model

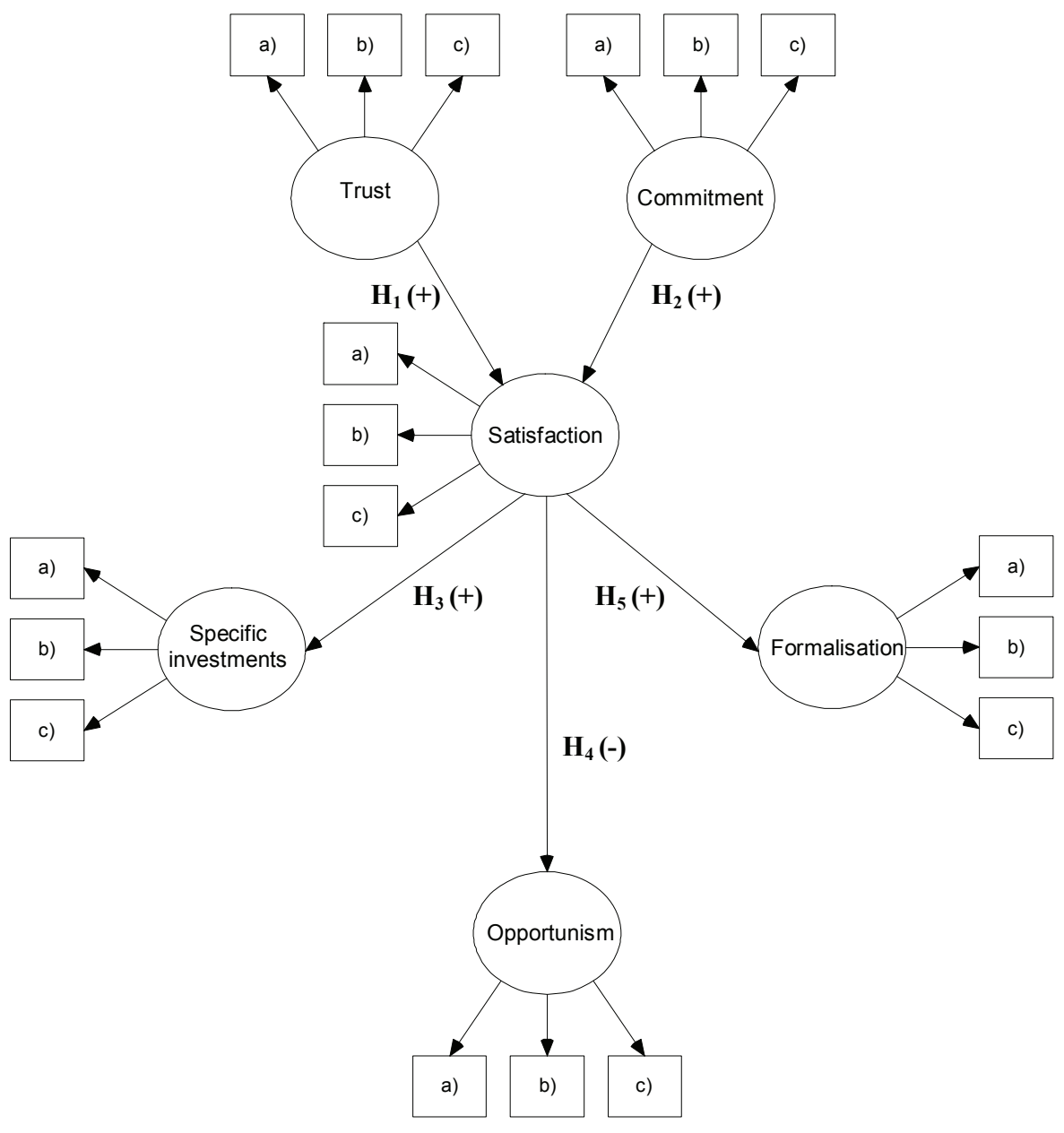




\subsubsection{Assessment of construct validity and reliability}

Several measures were used to assess the validity and reliability of the six constructs used in this study (see Table 3). Convergent validity is the extent to which the individual items in a construct share variance between them (Hair et al., 2006) and is measured based on the variance extracted from each construct. The variance extracted for all constructs exceeded the recommended $50 \%$ ranging between $59.7 \%$ to $80.3 \%$. Reliability is also considered when evaluating constructs. All constructs exhibited composite trait reliability levels that exceeded 0.7 [Hair et al., (2006), p.777], ranging between 0.83-0.92.

Table 2 Inter-construct correlations and summary statistics

\begin{tabular}{|c|c|c|c|c|c|c|}
\hline Variable & Satisfaction & Trust & Commitment & $\begin{array}{l}\text { Specific } \\
\text { assets }\end{array}$ & Opportunism & Formalisation \\
\hline Satisfaction & .896 & & & & & \\
\hline Trust & 0.781 & .834 & & & & \\
\hline Commitment & 0.601 & 0.528 & .896 & & & \\
\hline Specific assets & -0.099 & -0.114 & -0.008 & .853 & & \\
\hline Opportunism & -0.695 & -0.719 & -0.481 & 0.215 & .853 & \\
\hline Formalisation & 0.534 & 0.490 & 0.267 & 0.052 & -0.452 & .773 \\
\hline $\begin{array}{l}\text { Variance } \\
\text { extracted }\end{array}$ & $80.3 \%$ & $69.6 \%$ & $80.3 \%$ & $72.7 \%$ & $72.7 \%$ & $59.7 \%$ \\
\hline $\begin{array}{l}\text { Composite trait } \\
\text { reliability }\end{array}$ & 0.90 & 0.85 & 0.92 & 0.90 & 0.87 & 0.83 \\
\hline
\end{tabular}

Notes: Diagonal elements are the square root of the average variance extracted (AVE) between the constructs and their measures. The off-diagonal elements are correlations between the constructs. For discriminant validity, diagonal elements should be larger than the off-diagonal elements in the same row and column.

Source: Duarte and Raposo (2010, p.467)

Discriminant validity examines whether the constructs are measuring distinct concepts (Hair et al., 2006) and is assessed by comparing the square root of the variance extracted to the inter-construct correlations. The square root of the variance extracted (AVE) should be larger than the corresponding inter-construct correlations (Duarte and Raposo, 2010) and this condition was met in all cases (see Table 3). Consequently, the-model exhibited discriminant validity. Nomological validity means the direction of the causal relationships between the constructs is consistent with theory (see Figure 2). The construct relationships were significant and consistent with theory confirming nomological validity.

In summary, the recommended guidelines for convergent, discriminant and nomological validity, as well as construct reliability, were all met. Therefore, it is concluded that the measurement properties and some structural relationships of the model applied in Canadian business relationships indicate acceptable validity and reliability.

\section{Results}

The structural model's chi-square was 220.204 with 129 degrees of freedom. This chi-square was statistically significant $(p=0.000)$. As is common practice, the other fit 
statistics were re-examined. The normed chi-square $\left(X^{2} / d f\right)$ was 1.707 while the NFI was 0.90 , the IFI was 0.95 , the TLI was 0.94 , the CFI was 0.95 , and RMSEA was 0.069 (confidence interval 90\%: 0.053-0.084). All of the fit statistics are well within recommended guidelines. Furthermore, four out of five hypothesised relationships in the structural model were significant $(p=0.000)$ having standardised regression weights ranging between $0.255-0.718$ (see Table 2). Subsequently, four hypotheses were supported in this study's conceptual model.

Table 3 Tests of hypotheses

\begin{tabular}{lccccc}
\hline Hypothesis & $\begin{array}{c}\text { Exogenous } \\
\text { construct }\end{array}$ & $\begin{array}{c}\text { Endogenous } \\
\text { construct }\end{array}$ & $\begin{array}{c}\text { Regression } \\
\text { weight }\end{array}$ & Significance & Finding \\
\hline 1 & Trust & Satisfaction & 0.662 & 0.000 & Supported \\
2 & Commitment & Satisfaction & 0.255 & 0.000 & Supported \\
3 & Satisfaction & Specific & -0.109 & 0.209 & Not supported \\
4 & Satisfaction & Opportunism & -0.718 & 0.000 & Supported \\
5 & Satisfaction & Formalisation & 0.544 & 0.000 & Supported \\
\hline
\end{tabular}

\section{Discussion}

As hypothesised, trust and commitment have a positive association with satisfaction in support of Hypotheses 1 and 2. Specifically, this Canadian study shows a strong positive associations in the RM portion of the model, which includes the association between trust and satisfaction (regression weight $=0.66$ ), and the association between commitment and satisfaction (regression weight $=0.26$ ). Some research suggest no sequential logic among these three concepts, and simply includes all three concepts (i.e., trust, commitment, and satisfaction) as elements of relationship quality (Rauyruen and Miller, 2007; Skarmeas et al., 2008; Skarmeas and Robson, 2008). However, satisfaction is a positive affective state resulting from the appraisal of all aspects of one organisation's working relationship with another (Geyskens et al., 1999), which presumes that there is an evaluation or judgment that takes place about previous experiences with another organisation (Oliver, 1997; Wilson, 1995). It is highly likely that these previous experiences include feelings of trust and commitment between the buyer-supplier (Geyskens et al., 1999; Parsons, 2002). In summary, satisfaction may be more logically positioned as the outcome of trust and commitment based on the conceptual definition of satisfaction as a subsequent judgment.

Also as hypothesised (i.e., Hypothesis 4), this study shows the highest negative association in the model between satisfaction and opportunism (regression weight = -0.72). This supports findings in previous studies (Anderson, 1988; Pfeffer and Salancik, 1978; Ping, 2007; Ping, 1993). As mentioned before, as satisfaction with a relationship declines and becomes less rewarding, organisations are more likely to emit 'negative' behaviours such as opportunism or 'surreptitious self-interest seeking' Ping (2007, p.41). The results suggest the opposite is likely true, that high levels of satisfaction in a relationship dampen the likelihood that business partners will be opportunistic.

Contrary to predictions (i.e., Hypothesis 3), satisfaction does not have a significant positive association with specific investments. In hindsight, there are conflicting results 
in the literature regarding the relationship of specific investments with satisfaction. For example, and contrary to this study's prediction, Payan and Svensson (2007) predict and find a negative relationship between specific assets and satisfaction. They suggest this because of the potential threat of specific assets (i.e., the investment in dedicated activities with one organisation cannot be used with other organisations). Heide and John (1992) suggest that “... specific investments will reduce an organisation's control because of the dependence that is created. Dependence arises from investments in specific assets because they make the focal exchange partner irreplaceable or replaceable only at a cost" (p.35). This lack of control may be associated with an organisation's negative judgment (i.e., satisfaction) about its relationship with the organisation requiring the specific asset. However, in the consumer market of high end cosmetics, Chiou and Droge's (2006) research suggest that satisfaction does positively influence specific asset investment (considered a switching cost) by consumers.

Results also indicate that there is a significant positive association between satisfaction and formalisation, which suggests that Hypothesis 5 is supported. The results yielded by the analysis in the present study support the argument that satisfaction is a key factor influencing the channel members' inclination to engage in collective activities (Geyskens et al., 1999; Schul et al., 1985; Skarmeas and Robson, 2008), comprising information exchange (Ha and Muthaly, 2008).

\section{Conclusions and limitations}

This Canadian study has made several contributions to the B2B literature. First, this study includes both RM concepts (i.e., trust, commitment and satisfaction) and transaction cost theory concepts (i.e., specific investments, opportunism and formalisation) because it is likely that business success may be motivated by both theories (i.e., relationship characteristics, such as trust, and/or transactional outcomes). A review of the literature indicates that rarely are the RM concepts examined in the same inter-organisational study along with the transaction cost theory concepts.

Second, this study indicates strong positive associations between the RM constructs trust and satisfaction and between commitment and satisfaction. These results support previous studies, which indicate that trust serves as an antecedent to satisfaction (Grewal et al., 1999; Razzaque and Boon, 2003; Schul et al., 1985). As pointed out by Gekskens et al. (1998), "When a channel member trusts its partner, it will feel secure by way of an implicit belief that the actions of the partner will result in positive outcomes or not result in negative outcomes [i.e., trust]. This evaluation should lead to high satisfaction" (p.240). However, the results do not support other studies (Ulaga and Eggert, 2006) that suggest satisfaction has a strong influence on trust in a B2B setting. The results of this study also support the positioning of commitment as an antecedent to satisfaction (Farrelly and Quester, 2005; Mohr and Spekman, 1994). For example, if a buyer prioritises a relationship with a particular seller, the buyer will stress the accuracy in specifying requirements and in involving the seller in key decisions. In brief, the buyer will be committed. Clearer specifications and more involvement make it easier for the seller to fulfil the buyer's expectations, which lead to a positive evaluation about the relationship (i.e., satisfaction with the relationship).

Third, this study shows a negative association between satisfaction and opportunism (regression weight $=-0.71$ ), which support findings in previous studies (Anderson, 1988; 
Pfeffer and Salancik, 1978; Ping, 2007, 1993). As mentioned previously, as satisfaction with a relationship declines and becomes less rewarding, organisations are more likely to emit 'negative' behaviours such as opportunism or 'surreptitious self-interest seeking' [Ping, (2007), p.41]. The opposite is most likely true, that high levels of satisfaction in a relationship dampen the likelihood that business partners will be opportunistic. In this regard, working to ensure satisfaction in a relationship serves as a safeguard against possible future risks (e.g., opportunism).

Fourth, although satisfaction is not positively associated to specific investments this provides some insight about conflicting results reported in the literature. Because this study predicted a positive relationship between satisfaction and specific investments and others have predicted and shown a negative relationship between satisfaction and specific investments (Payan and Svensson, 2007), this may indicate that there may be other important moderators and/or mediators between satisfaction and specific investments. Payan and Svensson (2007) suggest that "Unless specific assets are matched equally between both partners, specific assets will not be viewed as a fair negotiation point between organizations" (p.807). This is supported by Jap and Ganesan (2000) who suggest that mutual dependence (investment) has an effect on satisfaction. In regard to the negative specific assets-satisfaction link, Payan and Svensson (2007) suggest that "the investment in specific assets reduces an organization's control and increases dependence because these assets cannot be used with other organizations (Heide and John, 1992). The invested organization's lack of control and increased dependence is likely to result in a lowered level of satisfaction with the relationship" (p.807). Testing a model with dependence as a moderator or mediator between satisfaction and specific investments may explain these conflicting predictions and results.

Finally, the positive relationship between satisfaction and formalisation suggests the importance of satisfaction as a core construct of relationship quality (Palmatier et al., 2006; Skarmeas and Robson, 2008). Farrelly and Quester (2005) maintain that "satisfaction is a key evaluative outcome of relationship interaction and, as such, is likely to be an indicator of relationship renewal" (p.213). The influence of satisfaction on formalisation in the present study may indicate that satisfaction also plays an important role in the establishment of routines and in distribution of tasks in the relationships. The division of tasks and information routines may reduce information asymmetry, inhibit dysfunctional behaviour and entail increased efficiency (Gilliland and Bello, 1997; Jaworski et al., 1993; Ouchi and Maguire, 1975). However, the role of satisfaction in business relationships is still unclear [Farrelly and Quester, (2005), p.213]. Satisfaction is formed by keeping promises (Oliver, 1997) and is formed in an iterative process (Farrelly and Quester, 2005; Oliver, 1999), which indicates that it may be difficult to measure antecedents and postcedents of satisfaction in a survey based on questionnaires. To elaborate on the concept and role of satisfaction, future research should consider longitudinal studies and multiple methods when attempting to clarify the iterative process leading to increased satisfaction, possible antecedents and outcomes.

Although the results of this study confirm four hypotheses out of five, there are some research limitations that need to be acknowledged. For example, the sample used in this study only included Canadian organisations of varying sizes. This may limit the ability to generalise findings to just large, medium or smaller sized organisations and organisations in other countries or contextual settings (e.g., culture). Another limitation is the sample covers a variety of business to business relationships (i.e., it tests the relationship between manufacturers and suppliers; service organisations and suppliers; public organisations 
and suppliers) and not specific to one organisation-supplier dyad. These limitations surface the opportunity to conduct future research in specific business to business relationships among different countries or cultures. A suggestion for future research is to test competing models that vary in terms of the positioning of relationship quality facets of satisfaction, trust, and commitment with important relationship outcomes across a broad spectrum of contexts. This research would be informative and may advance the field in a significant fashion.

Other constructs might be included in the future testing of the importance of satisfaction as a mediating variable between trust and commitment on the one hand, and important outcomes. For example, the above discussion suggests that dependence may be an important moderator or mediator of the relationship between satisfaction and both specific assets and formalisation. Similarly, the relationship between trust and control needs to be more thoroughly examined. For example, Huemer et al. (2009) recently suggested that trust may substitute for or complement control and vice versa under certain conditions. In addition, other constructs that may be added include cooperation because it has been shown to have a significant association with the quality of relationships (Mohr and Spekman, 1994; Morgan and Hunt, 1994; Payan and Svensson, 2007) based the type of industry (Felzensztein and Gimmon, 2008) or based on the culture/subculture (Felzensztein and Gimmon, 2007).

\section{References}

Andaleeb, S.S. (1996) 'An experimental investigation of satisfaction and commitment in marketing channels: the role of trust and dependence', Journal of Retailing, Vol. 72, No. 1, p.77.

Anderson, E. (1985) 'The salesperson as outside agent of employee: a transaction cost analysis', Marketing Science, Vol. 4, No. 3, p.234.

Anderson, E. (1988) 'Transaction costs as determinants of opportunism in integrated and independent sales forces', Journal of Economic Behavior and Organization, Vol. 9, No. 3, p.247.

Anderson, E. and Weitz, B. (1992) 'The use of pledges to build and sustain commitment in distribution channels', JMR, Journal of Marketing Research, Vol. 29, No. 1, p.18.

Anderson, J.C. and Narus, J.A. (1990) 'A model of distributor firm and manufacturer firm working partnership', Journal of Marketing, Vol. 54, No. 1, p.42.

Anderson, J.C., Hakansson, H. and Johanson, J. (1994) 'Dyadic business relationships within a business network context', Journal of Marketing, Vol. 58, No. 4, p.1.

Atkin, T.S. and Rinehart, L.M. (2006) 'The effect of negotiation practices on the relationship between suppliers and customers', Negotiation Journal, Vol. 22, No. 1, p.47.

Bakker, M., Leenders, R.T.A.J., Gabbay, S.M., Kratzer, J. and Engelen, J.M.L.V. (2006) 'Is trust really social capital? Knowledge sharing in product development projects', The Learning Organization, Vol. 13, No. 6, p.594.

Bansal, H.S., Irving, P.G. and Taylor, S.F. (2004) 'A three-component model of customer commitment to service providers', Academy of Marketing Science Journal, Vol. 32, No. 3, p.234.

Barclay, D.W. and Smith, J.B. (1997) 'The effects of organizational differences and trust on the effectiveness of selling partner relationships', Journal of Marketing, Vol. 61, No. 1, p.3.

Barry, J.M., Dion, P. and Johnson, W. (2008) 'A cross-cultural examination of relationship strength in B2B services', The Journal of Services Marketing, Vol. 22, No. 2, p.114. 
Bergen, M., Dutta, S. and Walker, O.C., Jr. (1992) 'Agency relationships in marketing: a review of the implications and applications of agency and related theories', Journal of Marketing, Vol. 56, No. 3, p.1.

Buvik, A. and Reve, T. (2001) 'Asymetrical deployment of specific assets and contractual safeguarding in industrial purchasing relationships', Journal of Business Research, Vol. 51, No. 2, p.101.

Caceres, R.C. and Paparoidamis, N.G. (2007) 'Service quality, relationship satisfaction, trust, commitment and business-to-business loyalty', European Journal of Marketing, Vol. 41, Nos. 7/8, p.836.

Campbell, D. (1955) 'The informant in quantitative research', American Journal of Sociology, Vol. 60, No. 4, pp.339-342.

Chiou, J-S. and Droge, C. (2006) 'Service quality, trust, specific asset investment, and expertise: direct and indirect effects in a satisfaction-loyalty framework', Academy of Marketing Science Journal, Vol. 34, No. 4, p.613.

Coote, L.V., Forrest, E.J. and Tam, T.W. (2003) 'An investigation into commitment in non-Western industrial marketing relationships', Industrial Marketing Management, Vol. 32, No. 7, p.595.

Coulter, K.S. and Coulter, R.A. (2003) 'The effects of industry knowledge on the development of trust in service relationships', International Journal of Research in Marketing, Vol. 20, No. 1, p.31.

Dahlstrom, R. and Nygaard, A. (1999) 'An empirical investigation of ex post transaction costs in franchised distribution channels', JMR, Journal of Marketing Research, Vol. 36, No. 2, p.160.

Dorsch, M.J., Swanson, S.R. and Kelley, S.W. (1998) 'The role of relationship quality in the stratification of vendors as perceived by customers', Academy of Marketing Science Journal, Vol. 26, No. 2, p.128.

Duarte, M. and Davies, G. (2004) 'Trust as a mediator of channel power', Journal of Marketing Channels, Vol. 11, Nos. 2/3, p.77.

Duarte, P.A.O. and Raposo, M.L.B. (2010) 'A PLS model to study brand preference an applicxation to the mobile phone market', in Vinzi, V.E. (Ed.): Handbook of Partial Least Squares: Concepts, Methods, and Applications, pp.449-485, Springer, New York.

Farrelly, F.J. and Quester, P.G. (2005) 'Examining important relationship quality constructs of the focal sponsorship exchange', Industrial Marketing Management, Vol. 34, No. 3, p.211.

Felzensztein, C. and Gimmon, E. (2007) 'The influence of culture and size upon inter-firm marketing cooperation', Marketing Intelligence and Planning, Vol. 25, No. 4, p.377.

Felzensztein, C. and Gimmon, E. (2008) 'Industrial clustes and social netrworking for enhancing inter-firm cooperation: the case of natural resources-based industries in Chile', Journal of Business Market Management, Vol. 2, No. 4, pp.187-202.

Ganesan, S. (1994) 'Determinants of long-term orientation in buyer-seller relationships', Journal of Marketing, Vol. 58, No. 2, p.1.

Garbarino, E. and Johnson, M.S. (1999) 'The different roles of satisfaction, trust, and commitment in customer relationships', Journal of Marketing, Vol. 63, No. 2, pp.70-87.

Geyskens, I., Steenkamp, J-B.E.M. and Kumar, N. (1998) 'Generalizations about trust in marketing channel relationships using meta-analysis', International Journal of Research in Marketing, Vol. 15, No. 3, p.223.

Geyskens, I., Steenkamp, J-B.E.M. and Kumar, N. (1999) 'A meta-analysis of satisfaction in marketing channel relationships', JMR, Journal of Marketing Research, Vol. 36, No. 2, p.223.

Gilliland, D.I. and Bello, D.C. (1997) 'The effect of output controls, process controls, and flexibility on export channel performance', Journal of Marketing, Vol. 61, No. 1, p.22.

Grewal, R., Comer, J.M. and Mehta, R. (1999) 'Does trust determine satisfaction in marketing channel relationships? The moderating role of exchange partner's price competitiveness', Journal of Business to Business Marketing, Vol. 6, No. 1, p.1. 
Ha, H-Y. and Muthaly, S. (2008) 'Alternative retailer-partner relationships: the role of satisfaction', Int. J. Business Excellence, Vol. 1, Nos. 1/2, pp.32-54.

Hair, J.F., Black, W., Babin, B., Anderson, R. and Tatham, R. (2006) Multivariate Data Analysis, 6th ed., Pearson Prentice Hall, Upper Saddle River, NJ.

Handfield, R.B. and Bechtel, C. (2002) 'The role of trust and relationship structure in improving supply chain responsiveness', Industrial Marketing Management, Vol. 31, No. 4, pp.367-382.

Hawkins, T., Knipper, M. and Strutton, D. (2009) 'Opportunism in buyer-supplier relations: new insights from quantitative synthesis', Journal of Marketing Channels, Vol. 16, No. 1, p.43.

Heide, J.B. and John, G. (1992) 'Do norms matter in marketing relationships?', Journal of Marketing, Vol. 56, No. 2, p.32.

Heide, J.B. and John, H. (1990) 'Alliances in industrial purchasing: the determinants of joint action in buyer-supplier relationships', Journal of Marketing Research, Vol. 27, No. 1, pp.24-37.

Hennig-Thurau, T. and Klee, A. (1997) 'The impact of customer satisfaction and relationship quality on customer retention: a critical reassessment and model development', Psychology and Marketing, Vol. 14, No. 8, pp.737-764.

Hennig-Thurau, T., Gwinner, K.P. and Gremler, D.D. (2002) 'Understanding relationship marketing outcomes: an integration of relational benefits and relationship quality', Journal of Service Research: JSR, Vol. 4, No. 3, p.230.

Hewett, K., Money, R.B. and Sharma, S. (2002) 'An exploration of the moderating role of buyer corporate culture in industrial buyer-seller relationships', Academy of Marketing Science Journal, Vol. 30, No. 3, p.229.

Huemer, L., Boström, G. and Felzensztein, C. (2009) 'Control-trust interplays and the influence paradox: a comparative study of MNC-subsidiary relationships', Industrial Marketing Management, Vol. 38, No. 5, p.520.

Huntley, J.K. (2006) 'Conceptualization and measurement of relationship quality: linking relationship quality to actual sales and recommendation intention', Industrial Marketing Management, Vol. 35, No. 6, p.703.

Hutchinson, D., Wellington, W.J., Saad, M. and Cox, P. (2010) 'Refining value-based differentiation in business relationships: a study of the higher order relationship building blocks that influence behavioural intentions', Industrial Marketing Management, Vol. 40, No. 3, p.465.

Ivens, B.S. (2004) 'How relevant are different forms of relational behavior? An empirical test based on MacNeil's exchange framework', Journal of Business and Industrial Marketing, Vol. 19, No. 5, pp.300-309.

Jap, S.D. and Ganesan, S. (2000) 'Control mechanisms and the relationship life cycle: implications for safeguarding specific investments and developing commitment', JMR, Journal of Marketing Research, Vol. 37, No. 2, p.227.

Jaworski, B.J., Stathakopoulos, V. and Krishnan, H.S. (1993) 'Control combinations in marketing: conceptual framework and empirical evidence', Journal of Marketing, Vol. 57, No. 1, p.57.

John, G. (1984) 'An empirical investigation of some antecedents of opportunism in a marketing channel', Journal of Marketing Research, Vol. 21, No. 3, pp.278-289.

Johnson, M.S., Sivadas, E. and Garbarino, E. (2008) 'Customer satisfaction, perceived risk and affective commitment: an investigation of directions of influence', Journal of Services Marketing, Vol. 22, No. 5, pp.353-362.

Jöreskog, K. and Sorbom, D. (1976) LISREL III: Estimation of Linear Structural Equations Systes by Maximum Likelihood Methods, National Educational Resources, Inc., Chicago.

Klein, B., Crawford, R. and Alchian, A. (1978) 'Vertical integration, appropriable rents, and the competitive contracting process', The Journal of Law and Economics, Vol. 21, No. 2, pp.297-326.

Lang, B. and Colgate, M. (2003) 'Relationship quality, on-line banking and the information technology gap', The International Journal of Bank Marketing, Vol. 21, No. 1, p.29. 
Lee, T-R.J-S., Svensson, G. and Mysen, T. (2010) '“Antecedents' and 'postcedents' in relation to satisfaction in Taiwanese business relationships', International Journal of Procurement Management, Vol. 3, No. 2, pp.199-213.

Leonidou, L.C., Barnes, B.R. and Talias, M.A. (2006) 'Exporter-importer relationship quality: the inhibiting role of uncertainty, distance, and conflict', Industrial Marketing Management, Vol. 35, No. 5, p.576.

Lui, S., Wong, Y. and Liu, W. (2009) 'Asset specificity roles in interfirm cooperation: reducing opportunistic behavior or increasing cooperative behavior?', Journal of Business Research, Vol. 62, No. 11, p.1214.

Mayer, R.C., Davis, J.H. and Schoorman, F.D. (1995) 'An integrative model of organizational trust', The Academy of Management Review, Vol. 30, No. 3, pp.709-734.

Mohr, J. and Spekman, R. (1994) 'Characteristics of partnership success: partnership attributes, communication behavior, and conflict resolution techniques', Strategic Management Journal, Vol. 15, No. 2, p.135.

Moliner, M.A., Sánchez, J., Rodríguez, R.M. and Callarisa, L. (2007a) 'Perceived relationship quality and post-purchase perceived value', European Journal of Marketing, Vol. 41, Nos. 11/12, p.1392.

Moliner, M.A., Sánchez, J., Rodríguez, R.M. and Callarisa, L. (2007b) 'Relationship quality with a travel agency: The influence of the postpurchase perceived value of a tourism package', Tourism and Hospitality Research, Vol. 7, Nos. 3-4, pp.194-211.

Moorman, C., Deshpande, R. and Zaltman, G. (1993) 'Factors affecting trust in market research relationships', Journal of Marketing, Vol. 57, No. 1, p.81.

Moorman, C., Zaltman, G. and Deshpande, R. (1992) 'Relationships between providers and users of market research: the dynamics of trust within and between organizations', JMR, Journal of Marketing Research, Vol. 29, No. 3, p.314.

Morgan, R.M. and Hunt, S.D. (1994) 'The commitment-trust theory of relationship marketing', Journal of Marketing, Vol. 58, No. 3, pp.20-38.

Naude, P. and Buttle, F. (2000) 'Assessing relationship quality', Industrial Marketing Management, Vol. 29, No. 4, p.351.

Oliver, R. (1997) Satisfaction: A Behavioral Perspective on the Consumer, McGraw-Hill International Editions, New York.

Oliver, R.L. (1999) 'Value as excellence in the consumption experience', in Holbrook, M.B. (Ed.) Consumer Value: A Framework for Analysis and Research, pp.41-84, Routledge, London.

Ouchi, W.G. and Maguire, M.A. (1975) 'Organizational control - two functions', Administrative Science Quarterly, Vol. 20, No. 4, p.559.

Palmatier, R.W., Dant, R.P., Grewal, D. and Evans, K.R. (2006) 'Factors influencing the effectiveness of relationship marketing: a meta-analysis', Journal of Marketing, Vol. 70, No. 4, p.1.

Parkhe, A. (1993) 'Strategic alliance structuring: a game theoretic and transaction cost examination of interfirm cooperation', Academy of Management Journal, Vol. 36, No. 4, p.794.

Parsons, A.L. (2002) 'What determines buyer-seller relationship quality? An investigation from the buyer's perspective', Journal of Supply Chain Management, Vol. 38, No. 2, p.4.

Payan, J. and Svensson, G. (2007) 'Co-operation, coordination, and specific assets in inter-organisational relationships', Journal of Marketing Management, Vol. 23, Nos. 7/8, p.797.

Pfeffer, J. and Salancik, G.R. (1978) The External Control of Organizations: A Resource Dependence Perspective, Harper \& Row, New York.

Ping, R. (2007) 'Salesperson-employer relationships: salesperson responses to relationship problems and their antecedents', The Journal of Personal Selling and Sales Management, Vol. 27, No. 1, p.39. 
Ping, R.A., Jr. (1993) 'The effects of satisfaction and structural constraints on retailer exiting, voice, loyalty, opportunism, and neglect', Journal of Retailing, Vol. 69, No. 3, p.320.

Provan, K.G. and Skinner, S.J. (1989) 'Interorganizational dependence and control as predictors of opportunism in dealer-supplier relations', Academy of Management Journal, Vol. 32, No. 1, p.202.

Rauyruen, P. and Miller, K.E. (2007) 'Relationship quality as a predictor of B2B customer loyalty', Journal of Business Research, Vol. 60, No. 1, p.21.

Razzaque, M.A. and Boon, T.G. (2003) 'Effects of dependence and trust on channel satisfaction, commitment and cooperation', Journal of Business to Business Marketing, Vol. 10, No. 4, p.23.

Rindfleisch, A. and Heide, J.B. (1997) 'Transaction cost analysis: past, present, and future applications', Journal of Marketing, Vol. 61, No. 4, p.30.

Roath, A.S. and Sinkovics, R.R. (2006) 'Utilizing relational governance in export relationships: leveraging learning and improving flexibility and satisfaction', Advances in International Marketing, Vol. 16, p.157.

Roberts, K., Varki, S. and Brodie, R. (2003) 'Measuring the quality of relationships in consumer services: an empirical study', European Journal of Marketing, Vol. 37, Nos. 1/2, p.169.

Ruyter, K.D., Moorman, L. and Lemmink, J. (2001) 'Antecedents of commitment and trust in customer-supplier relationships in high technology markets', Industrial Marketing Management, Vol. 30, No. 3, pp.271-286.

Schoorman, F.D., Roger, C.M. and James, H.D. (2007) 'An integrative model of organizational trust: past, present, and future', Academy of Management Review, Vol. 32, No. 2, p.344.

Schul, P.L., Little, T.E., Jr. and Pride, W.M. (1985) 'Channel climate: its impact on channel members' satisfaction', Journal of Retailing, Vol. 61, No. 2, p.9.

Scott, W.R. (1987) Organizations: Rational, Natural, and Open Systems, Prentice Hall, New Jersey.

Shamdasani, P.N. and Balakrishnan, A.A. (2000) 'Determinants of relationship quality and loyalty in personalized services', Asia Pacific Journal of Management, Vol. 17, No. 3, p.399.

Sharma, A. and Pillai, K.G. (2003) 'The impact of transactional and relationship strategies in business markets: an agenda for inquiry', Industrial Marketing Management, Vol. 32, pp.623-626.

Skarmeas, D. and Robson, M. (2008) 'Determinants of relationship quality in importer-exporter relationships', British Journal of Management, Vol. 19, No. 2, p.171.

Skarmeas, D., Katsikeas, C., Spyropoulou, S. and Salehi-Sangari, E. (2008) 'Market and supplier characteristics driving distributor relationship quality in international marketing channels of industrial products', Industrial Marketing Management, Vol. 37, No. 1, p.23.

Skinner, S.J., Gassenheimer, J.B. and Kelley, S.W. (1992) 'Cooperation in supplier-dealer relations', Journal of Retailing, Vol. 68, No. 2, p.174.

Svensson, G., Mysen, T. and Payan, J. (2009) 'Balancing the sequential logic of quality constructs in manufacturing-supplier relationships - causes and outcomes', Journal of Business Research, Vol. 63, pp.1209-1214.

Svensson, G., Mysen, T. and Payan, J. (2010) 'Balancing the sequential logic of quality constructs in manufacturing-supplier relationships - causes and outcomes', Journal of Business Research, Vol. 63, No. 11, p.1209.

Terpend, R., Tyler, B., Krause, D. and Handfield, R. (2008) 'Buyer-supplier relationships: derived value over two decades', Journal of Supply Chain Management, Vol. 44, No. 2, p.28.

Ulaga, W. and Eggert, A. (2006) 'Relationship value and relationship quality: broadening the nomological network of business-to-business relationships', European Journal of Marketing, Vol. 40, Nos. 3/4, p.311. 
Walter, A., Mueller, T.A. and Helfert, G. (2000) 'The impact of satisfaction, trust, and relationship value on commitment: theoretical considerations and empirical results', Paper presented at the 2000 IMP Conference, Europe, available at http://www.bath.ac.uk/imp/trackb.htm (accessed on August 2004).

Walter, A., Muller, T., Helfert, G. and Ritter, T. (2003) 'Functions of industrial supplier relationships and their impact on relationship quality', Industrial Marketing Management, Vol. 32, No. 2, pp.159-169.

Weiss, A.M. and Anderson, E. (1992) 'Converting from independent to employee salesforces: the role of perceived switching costs', JMR, Journal of Marketing Research, Vol. 29, No. 1, p.101.

Wetzels, M., Ruyter, K.D. and Birgelen, M.V. (1998) 'Marketing service relationships: the role of commitment', The Journal of Business and Industrial Marketing, Vol. 13, Nos. 4/5, p.406.

Williamson, O.E. (1975) Markets and Hierarchies, Analysis and Antitrust Implications: A Study in the Economics of Internal Organization, The Free Press, New York.

Wilson, D.T. (1995) 'An integrated model of buyer-seller relationships', Academy of Marketing Science Journal, Vol. 23, No. 4, pp.335-345.

Wong, A. and Sohal, A. (2002) 'An examination of the relationship between trust, commitment and relationship quality', International Journal of Retail and Distribution Management, Vol. 30, No. 1, p.34.

Wong, A. and Zhou, L. (2006) 'Determinants and outcomes of relationship quality: a conceptual model and empirical investigation', Journal of International Consumer Marketing, Vol. 18, No. 3, p.81.

$\mathrm{Xu}$, L. and Beamon, B.M. (2006) 'Supply chain coordination and cooperation mechanisms: an attribute-based approach', Journal of Supply Chain Management, Vol. 42, No. 1, p.4.

Young, L.C. and Wilkinson, I.F. (1989) 'The role of trust and co-operation in marketing channels: a preliminary study', European Journal of Marketing, Vol. 23, No. 2, p.109.

Zaheer, A., McEvily, B. and Perrone, V. (1998) 'Does trust matter? Exploring the effects of interorganizational and interpersonal trust on performance', Organization Science, Vol. 9, No. 2, p.141. 